\title{
Prey selection and dietary overlap among zooplanktivorous jellyfish and juvenile fishes in Prince William Sound, Alaska
}

\author{
Jennifer E. Purcell ${ }^{1, *}$, Molly V. Sturdevant ${ }^{2}$ \\ ${ }^{1}$ University of Maryland Center for Environmental Science, Horn Point Laboratory, PO Box 775, Cambridge, \\ Maryland 21613, USA \\ ${ }^{2}$ NOAA/NMFS, Alaska Fisheries Science Center, Auke Bay Laboratory, 11305 Glacier Highway, Juneau, \\ Alaska 99801, USA
}

\begin{abstract}
The potential for competition for food among zooplanktivorous species of gelatinous zooplankton and fishes has been the subject of much speculation. Here, we evaluate the dietary overlaps among 2 scyphomedusan species, Aurelia labiata and Cyanea capillata, 1 ctenophore species, Pleurobrachia bachei, 1 hydromedusan species, Aequorea aequorea var. albida, and juveniles (Age-0) of 4 forage fish species, walleye pollock Theragra chalcogramma, Pacific sandlance Ammodytes hexapterus, Pacific herring Clupea pallasi, and pink salmon Oncorhynchus gorbuscha. Zooplankton samples collected in July-August 1995 to 1998 showed great similarity among years (86 to $96 \%$ ), which allowed valid dietary comparisons between pelagic coelenterates and fishes collected in different years during that period. The predators fell into 2 groups, one that ate primarily crustacean prey (A. labiata, P. bachei, juvenile walleye pollock, sandlance, and herring), and another that ate mostly larvaceans (C. capillata, $A$. aequorea, and juvenile pink salmon). Species within the first group showed significant positive selection for crustacean prey and significant negative selection for larvaceans. The opposite trends were observed in the second group. Dietary overlaps were higher among crustacean-eating species $(63 \pm 13 \%)$ and larvacean-eating species $(66 \pm 10 \%)$ than when comparing crustacean- with larvacean-eating species $(24 \pm 14 \%)$. Dietary overlaps among pelagic coelenterate species $(41 \pm 21 \%)$ and among fish species $(42 \pm 25 \%)$ were similar, while overlaps between pelagic coelenterate and fish species averaged $50 \pm 21 \%$. These pelagic coelenterate and fish species were collected together in 45 purse seine sets taken in Prince William Sound in July 1999. We conclude that the diets of pelagic coelenterate and forage fish species overlap substantially, and that the species co-occur spatially and temporally. Therefore, the potential for competition for prey exists for these zooplanktivores in Prince William Sound.
\end{abstract}

KEY WORDS: Aurelia · Competition · Ctenophore · Cyanea · Herring · Pollock · Salmon · Sandlance $\cdot$ Zooplankton

\section{INTRODUCTION}

The relationships of jellyfish and ctenophores (grouped here as 'pelagic coelenterates') with fishes have

\footnotetext{
*Present address: Shannan Point Marine Center, 1900 Shannon Point Rd., Anacortes, Washington 98221, USA.

E-mail: purcell@hpl.umces.edu
}

been of particular interest because of the potential effects on commercially important fisheries. These interactions include predation on ichthyoplankton by pelagic coelenterates (reviewed by Purcell 1985, 1997, Arai 1988, Purcell \& Arai 2001), potential competition for prey between pelagic coelenterates, zooplanktivorous fishes and fish larvae (reviewed by Arai 1988, Purcell \& Arai 2001), predation by fishes on pelagic coe- 
lenterates (reviewed by Arai 1988, Ates 1988, Harbison 1993, Purcell \& Arai 2001), pelagic coelenterates as intermediate hosts of fish parasites (reviewed by Arai 1988, Purcell \& Arai 2001), and commensal associations between fishes and medusae (reviewed in Mansueti 1963, Purcell \& Arai 2001). Generally, the importance of these interactions to fish or pelagic coelenterate populations is unknown.

Although several authors have speculated on the potential importance of competition among zooplanktivorous pelagic coelenterates and fishes (e.g. Möller 1980, van der Veer 1985, Arai 1988, Bailey \& Houde 1989, Shiganova 1998), virtually no direct comparisons of diet and co-occurrence have been made. Although 2 recent studies reached different conclusions, any results probably would be specific to a particular situation. Purcell \& Grover (1990) directly compared the diets of post-yolksac herring with those of 7 co-occurring medusa species. The prey of larval herring (copepod nauplii and eggs, shelled protozoans, and bivalve veligers) were abundant $\left(41 \mathrm{l}^{-1}\right)$ in the environment, and predation on those prey by the gelatinous species was estimated to be only $0.2 \% \mathrm{~d}^{-1}$ of the standing stocks. The authors concluded that competition among the fish larvae and pelagic coelenterates was not occurring at that time. Vinogradov et al. (1996) estimated the consumption of mesozooplankon by the ctenophore Mnemiopsis leidyi and zooplanktivorous fishes (European anchovy Engraulis encrasicolus, European sprat Sprattus sprattus, and Mediterranean horse mackerel Trachurus mediterraneus) in the Black Sea. Biomass of zooplankton and fishes, and prey consumption by fishes were high until 1988, but decreased dramatically during the outbreak period of $M$. leidyi that began in 1989. Competition for food among the ctenophores and fishes was inferred.

The diets of various jellyfish species have been quantified in recent years, and prey selection has been determined for some species. Among hydromedusae, groups of species have similar diets - a group that eats hard-bodied prey, such as crustaceans (most anthomedusae other than pandeids, trachymedusae), a second group that eats soft-bodied prey, such as other gelatinous organisms (narcomedusae, pandeid anthomedusae), and a third that eats both hard- and soft-bodied prey (leptomedusae, including Aequorea spp.) (Purcell \& Mills 1988, Purcell 1997). The diets of fewer species of scyphomedusae have been examined. These include Pelagia noctiluca, Pseudorhiza haeckeli, Cyanea capillata, Chrysaora quinquecirrha, Stomolophus meleagris, and Aurelia aurita, which all consume a mixture of hard- and soft-bodied prey (Malej 1982, Fancett 1988, Brewer 1989, Larson 1991, Purcell 1992, Sullivan et al. 1994). Studies of prey selection by jellyfish, defined as the consumption of prey types in dispropor- tion to their abundance in the environments, illustrated that $C$. capillata, C. quinquecirrha, and Aequorea victoria show positive selection for ichthyoplankton (Fancett 1988, Purcell 1989, Purcell et al. 1994), but that those species and $A$. aurita show negative selection for copepods (Fancett 1988, Purcell 1989, Purcell et al. 1994, Sullivan et al. 1994).

Forage fishes, are small, schooling, zooplanktivorous fishes that form a critical trophic link between zooplankton and vertebrate consumers (Springer \& Speckman 1997). The diets of commercially important forage fishes, such as juvenile walleye pollock Theragra chalcogramma, Pacific herring Clupea pallasi, and pink salmon Oncorhynchus gorbuscha, have been examined for many locations and life stages. Diets of noncommercial forage species, such as Pacific sandlance Ammodytes hexapterus, are less well-known. All these species feed principally in the water column on zooplankton despite widely different life-history strategies and periods of nearshore residence in shallow water. Calanoid copepods are universally important prey (e.g. Manzer 1969, Kamba 1977, Field 1988, Coyle \& Paul 1992), with different species selected in different areas by the same predators. The fish generally and gradually select larger prey with growth and sometimes a change in habitat. A wide variety of mesozooplankton, macrozooplankton and nekton is consumed by juveniles during the spring and summer, including, occasionally, fish larvae; piscivory becomes more common among the larger juveniles and adults (e.g. Juanes 1994, Landingham et al. 1998, Mittelbach \& Persson 1998, Persson \& Hansson 1999, Willette et al. 1999).

Prince William Sound (PWS) has been the location of intensive ecological research since the 'Exxon Valdez' oil spill in 1989. It is a complex fjord-type estuary (Schmidt 1977) located on the northern margin of the Gulf of Alaska at $60^{\circ} \mathrm{N}, 146^{\circ} \mathrm{W}$, covering about 8800 $\mathrm{m}^{2}$ and having $3200 \mathrm{~km}$ of shoreline (Grant \& Higgens 1910) (Fig. 1). Many of the marine birds and mammals whose populations were injured by the oil spill feed on forage fishes, including the species mentioned above, as well as the capelin Mallotus villosus. The research presented here is part of the multi-investigator project, Alaska Predator Ecosystem eXperiment (APEX). PWS was surveyed to examine forage fish distribution and abundance along transects using acoustics and aerial mapping, with seining, trawling and underwater video for target verification. Additionally, the diets of forage fishes and pelagic coelenterates, and the abundance of their zooplankton prey were quantified (Sturdevant et al. 1997, 1998, Purcell 1999). A goal of the APEX project is to determine if the zooplankton foods available to forage fishes is limiting their populations and thereby inhibiting the recovery of piscivorous marine bird and mammal populations injured by the oil spill. 
Dietary overlap among the pelagic coelenterates and juveniles of zooplanktivorous fish species that we consider here (the scyphomedusae Aurelia labiata and Cyanea capillata, the ctenophore Pleurobrachia bachei, the hydromedusan Aequorea aequorea var. albida, and Age-0 walleye pollock, Pacific sandlance, Pacific herring, and pink salmon) is potentially of broad ecological importance. Species in the gelatinous genera Aurelia, Pleurobrachia, Cyanea, and Aequorea often occur in great abundance in the world's oceans (e.g. Hirota 1974, van der Veer 1985, Fancett 1988, Purcell \& Grover 1990, Båmstedt et al. 1997, Dawson \& Martin 2001, Purcell et al. 2001, Sparks et al. 2001). Walleye pollock, Pacific herring and pink salmon are highly abundant fish species that support important commercial fisheries in various areas of the North Pacific Ocean; similarly, species of sandlance and herring are fished in several northern oceans (FAO 1999a,b, National Marine Fisheries Service 1999). Fisheries researchers are particularly interested in biological processes, such as trophic interactions, that occur in the early life history of these fishes and that affect their abundance and recruitment to multi-billion-dollar fisheries. In the present study, we present zooplankton data and dietary data for these species during summer in PWS, as well as examine prey selection by each coelenterate and fish species and dietary overlap among

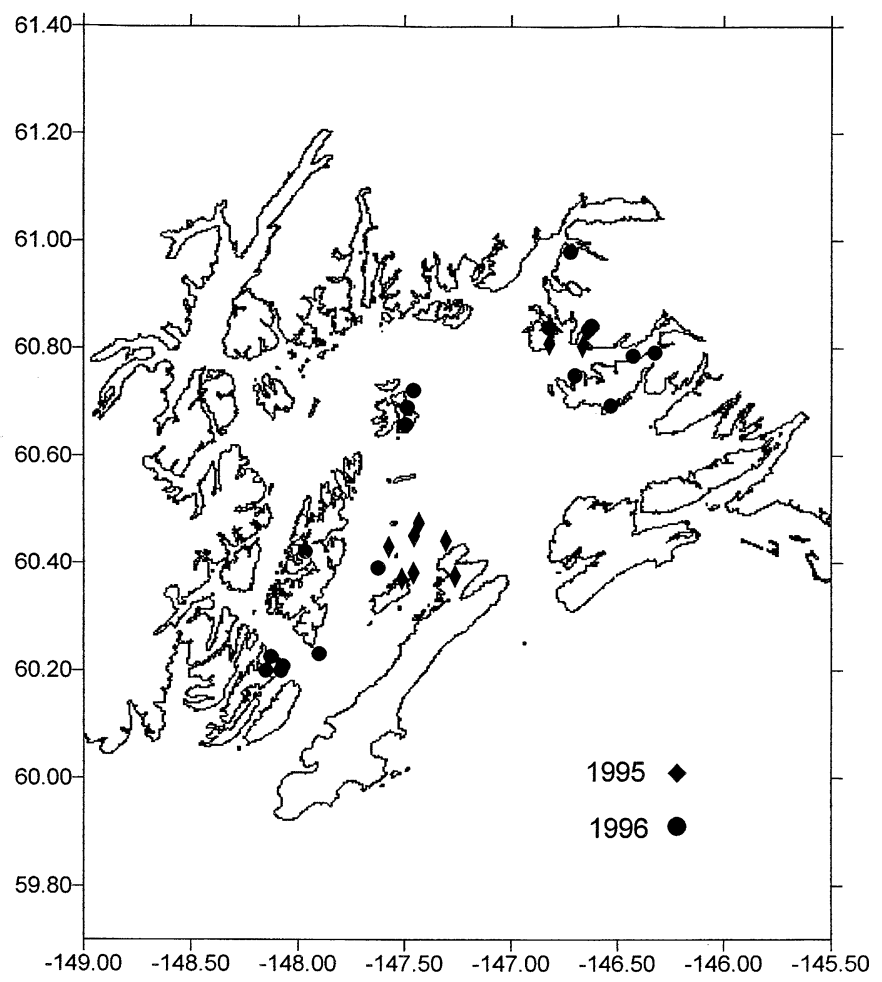

all the species. We then discuss the potential for competition among pelagic coelenterates and fishes for zooplankton prey in PWS.

\section{MATERIALS AND METHODS}

Sampling locations and dates. Three regions in PWS were established (northeast, central, southwest) (Fig. 1). Sampling for fishes and zooplankton occurred in daylight; schools were located and successfully sampled in 1995 and 1996. In 1997 and 1998, 4 stations were selected to represent each region. Sampling for pelagic coelenterates and zooplankton occurred in both daylight and darkness in 1997 and 1998. Sampling dates were 26 July to 10 August 1995, 16 to 28 July 1996, 29 July to 8 August 1997, and 14 to 20 July 1998. During fish sampling in 1995, interest in jellyfish developed due to obervations that they often were abundant in trawl catches, and large aggregations of jellyfish were observed by sea and air (Purcell et al. 2001). Fish dietary sampling was completed before funding for jellyfish was instated, which resulted in fishes and pelagic coelenterates being sampled in different years.

Zooplankton. Zooplankton was sampled during the day at the same times and locations that predators were

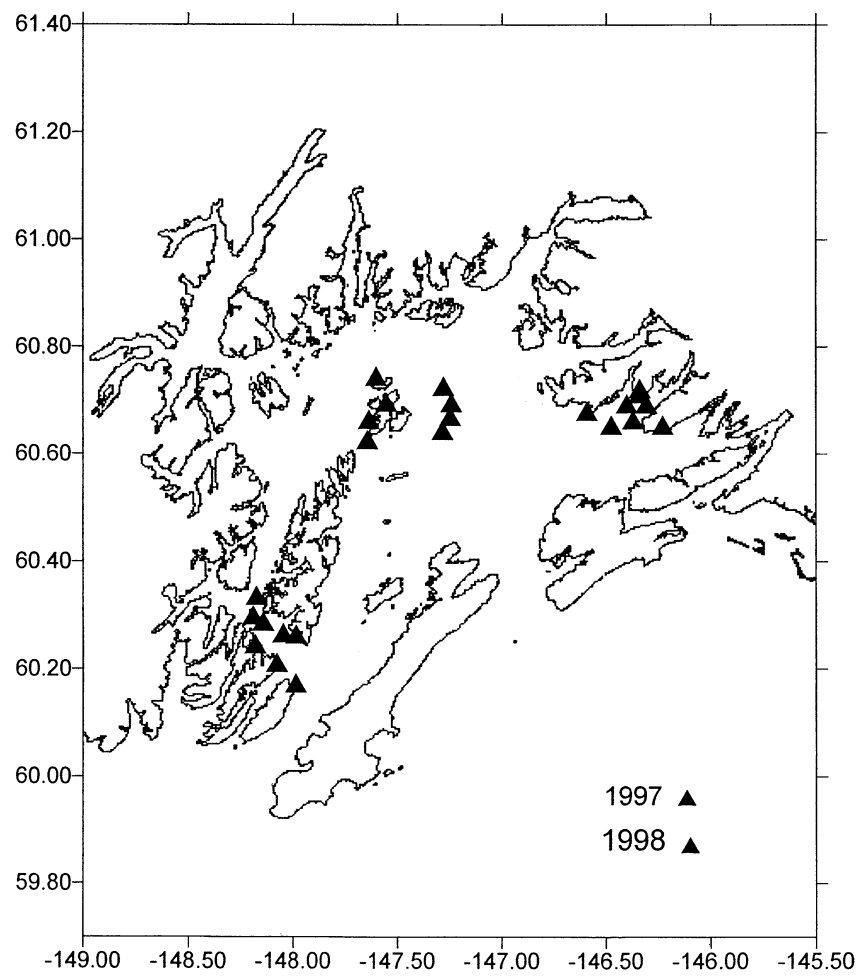

Fig. 1. Prince William Sound (PWS), south-central Alaska, USA. Locations of sampling stations for fishes and zooplankton in 1995 and 1996, and for pelagic coelenterates and zooplankton in 1997 and 1998 
collected for gut-content analysis in 1995 to 1998. Zooplankton samples were collected in vertical tows of plankton nets of $243 \mu \mathrm{m}$ mesh (from $20 \mathrm{~m}$ depth using a 0.5 m diameter Norpac net in 1995 and 1996, and from $60 \mathrm{~m}$ using a $0.2 \mathrm{~m}$ diameter bongo net in 1997 and 1998). Additional zooplankton samples from 1995 taken with a $303 \mu \mathrm{m}$ mesh Norpac net were used only for calculation of juvenile walleye pollock prey selection, because no $243 \mu \mathrm{m}$ mesh samples were available at those stations. Zooplankton percent composition did not differ among 243 and $303 \mu \mathrm{m}$ mesh samples (Sturdevant \& Willette 1999); therefore, calculations should not have been affected. Samples were preserved in $5 \%$ formalin solution. In the laboratory, the samples were split using a Folsom plankton splitter, and organisms were identified to general taxon and counted with the aid of a dissecting microscope. Large calanoid copepods were defined as those $>2.5 \mathrm{~mm}$ total length (TL); cyclopoid copepods were pooled with small calanoids, defined as those $\leq 2.5 \mathrm{~mm}$ TL. Numbers of each taxon were standardized to $1 \mathrm{~m}^{3}$ water volume, and grouped by general taxon. Minor components (primarily bivalve veligers and invertebrate eggs) were grouped as 'other'.

Pelagic coelenterates. Pelagic coelenterates for gutcontent analysis were dipped from near surface with a net on a $3.7 \mathrm{~m}$ pole. They were immediately preserved individually in $5 \%$ formalin solution made from $32 \mu \mathrm{m}$ filtered seawater. The pelagic coelenterates were dissected in the laboratory and all tissue and liquid examined for prey organisms, which were identified to general taxon as above.

Fishes. Forage fishes were collected during population surveys in PWS during 1995 and 1996, using fishing gear that was operated from chartered commercial fishing vessels (trawl and purse seine) and a $5 \mathrm{~m} \mathrm{(16')}$ skiff (beach seine) (Haldorson et al. 1997, 1998, Sturdevant \& Hulbert 2000, Sturdevant \& Willette 1999). In 1995 and 1996, a midwater trawl (mouth opening $50 \mathrm{~m}^{2}, 5$ to $1 \mathrm{~cm}$ mesh net with $0.3 \mathrm{~cm}$ liner and $500 \mu \mathrm{m}$ mesh cod-end) was fished for 20 to $35 \mathrm{~min}$ per haul at 2.5 to 3.0 knots. In 1996, a purse seine (200 m long by $20 \mathrm{~m}$ deep, $25 \mathrm{~mm}$ stretch mesh) was fished in shallow water and a beach seine $(37 \mathrm{~m}$ long, tapering from $5 \mathrm{~m}$ to $1.5 \mathrm{~m}$ deep, $20 \mathrm{~mm}$ to $10 \mathrm{~mm}$ stretch mesh) was fished on shore. Additional fish samples from surface aggregations were sampled with cast nets and dipnets. Subsamples of forage species were retained for diet studies by preserving 10 to 15 specimens in $10 \%$ buffered formalin-seawater solution in the field for later stomach analysis in the laboratory. After a minimum of $6 \mathrm{wk}$ in formalin solution, fish samples were transferred to $50 \%$ isopropanol for $\geq 10 \mathrm{~d}$ before stomach analysis was performed. Ten specimens of each species and size class were measured (mm standard fork length, FL; mg wet weight) per haul. Stomachs were excised, weighed and the contents removed. For this study, prey organisms were identified to general taxon and enumerated (see Sturdevant \& Hulbert 2000, Sturdevant \& Willette 1999).

Analyses. Zooplankton taxa in numbers $\mathrm{m}^{-3}$ were averaged among stations within each region and across regions for each year, and the percentages of the taxa were calculated from the means. Gut-content data (numbers of each prey taxon predator $^{-1}$ ) were averaged for each predator species among stations for each year, and percentages were calculated from the means. Then Schoener's (1974) percent similarity index (PSI) was used to compare zooplankton among regions each year, and among years, and the prey consumed among pelagic coelenterates and fish species. PSI is computed by summing the minimum percentages of all taxa shared between 2 species or years:

$$
\operatorname{PSI}_{j k}=1-0.5\left(\sum\left|P_{i j}-P_{i k}\right|\right)
$$

where $P$ is the numerical proportion of the $i$ th prey taxon in $n$ taxonomic categories consumed by Species $j$ and $k$, for example.

Pearre's (1982) electivity index, $C$, was used to test for significant predator selection from available zooplankton using chi-square analyses with 1 degree of freedom. Electivity indices were calculated for each predator species using data on the numbers of prey in the diets relative to those available in the plankton samples at each station:

$$
\chi^{2}=\frac{n\left(\left|a_{d} b_{e}-b_{d} a_{e}\right|-n / 2\right)^{0.5}}{a b c d}
$$

where $a$ is the number of individuals in species $a$ and $b$ is the number of individuals in all other taxa in the diet (subscripts $d$ ) and in the environment (subscripts e), respectively; $a=a_{d}+a_{e i} b=b_{d}+b_{e i} c=a_{d}+b_{c i}$ and $d=a_{c}+b_{e i}$ and $n=a+b+c+d$. This was repeated for each taxon of interest:

$$
C= \pm\left(\chi^{2} \div n\right)^{0.5}
$$

We present the data as the percentages of significant $(p<0.05)$ electivity values relative to the total number of stations where zooplankton and dietary data were collected together for each predator species.

\section{RESULTS}

\section{Zooplankton}

Mean total zooplankton density in all regions of PWS ranged from 791 to 6117 organisms $\mathrm{m}^{-3}$ in the upper 20 to $60 \mathrm{~m}$ water column in all years of the study; however, for the purposes of the prey selection 
and diet similarity analyses, the relative numerical composition of the suite of zooplankton taxa is critical, rather than abundance. The percentages of the various zooplankton taxa were very similar among regions and years (Fig. 2). The zooplankton samples were dominated by small calanoid and cyclopoid copepods, Pseudocalanus sp., Oithona similis, Acartia spp., and Centropages abdominalis (Sturdevant \& Willette 1999), larvaceans, cladocerans, and bivalve larvae. Comparisons of the zooplankton (243 $\mu \mathrm{m}$ mesh) population compositions showed great similarity in each year amongregions (northeast, central, southwest). PSI values averaged $85 \pm 11 \%$ in 1995 to 1998 (Table 1). In 1998, the northeastern region was least similar compared with the other regions due to high densities of bivalve larvae. The high degree of similarity
Table 1. Percent similarity indices (PSI) comparing zooplankton population composition (243 $\mu \mathrm{m}$ mesh) by regions during summer in different years in Prince William Sound (PWS), Alaska. -: no data

\begin{tabular}{|lcccc|}
\hline Regions & \multicolumn{4}{c|}{ PSI (\%) } \\
& $\begin{array}{c}\text { 26 Jul-10 Aug } \\
1995\end{array}$ & $\begin{array}{c}\text { 16-28 Jul } \\
\text { 29 Jul-8 Aug } \\
\text { 1996 }\end{array}$ & $\begin{array}{c}\text { 19-20 Jul } \\
1997\end{array}$ \\
\hline North vs Central & 81.9 & 92.0 & 86.3 & 72.8 \\
North vs South & - & 92.0 & 95.4 & 60.7 \\
Central vs South & - & 96.8 & 88.7 & 87.7 \\
& & & & \\
\hline
\end{tabular}

among zooplankton samples allowed us to combine regions for further analyses. Zooplankton composition was very similar among years when regions were combined, with PSI values averaging $90.3 \pm$ $3.6 \%$ (Table 2), which allowed us to make valid comparisons among fish and pelagic coelenterate diets from different years.

Central

South
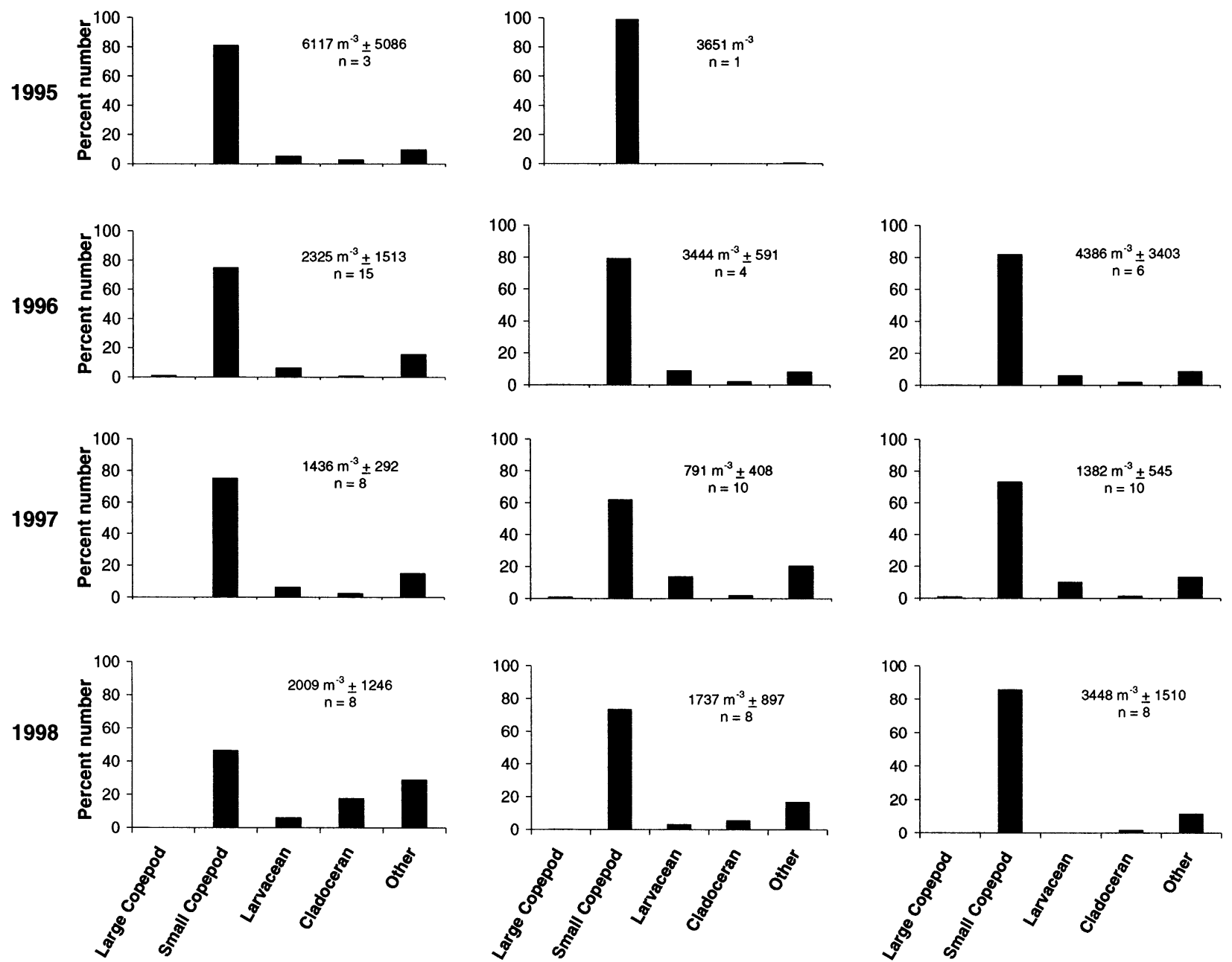

Fig. 2. Percentage composition of zooplankton taxa by region (northeast, central, southwest) and year (1995 to 1998). Total zooplankton densities (mean no. $\mathrm{m}^{-3} \pm 1 \mathrm{SE}$ ) and the numbers of samples are shown in each panel 
Table 2. Percent similarity indices (PSI) comparing zooplankton population composition ( $243 \mu \mathrm{m}$ mesh) in July and August by year in Prince William Sound (PWS), Alaska

\begin{tabular}{|lc|}
\hline Years & PSI $(\%)$ \\
\hline 1995 vs 1996 & 90.4 \\
1995 vs 1997 & 86.6 \\
1995 vs 1998 & 86.0 \\
1996 vs 1997 & 95.6 \\
1996 vs 1998 & 91.0 \\
1997 vs 1998 & 92.3 \\
\hline
\end{tabular}

\section{Diets of pelagic coelenterates and fishes}

Because of the lower PSI values for zooplankton in 1998 compared with other years and the standard use of $243 \mu \mathrm{m}$ mesh nets after 1995, we focused on comparisons between fish in 1996 and pelagic coelenterates in 1997. The pelagic coelenterate diet data presented here were from 1997 for Aurelia labiata, Pleurobrachia bachei, and Cyanea capillata, and from 1998 for Aequorea aequorea, for which dietary data were unavailable in 1997 (Fig. 3, Table 3). Of the gelatinous species, only $P$. bachei consumed almost exclusively crustacean prey. The other species ate crustaceans, larvaceans, and bivalve veligers; however, A. labiata consumed primarily hard-bodied prey (95\%), while C. capillata and $A$. aequorea consumed high percentages of larvaceans (83 and $77 \%$, respectively). The species of prey could not consistently be identified in the gut contents, and so are not reported here.

The diets of the fish species presented here were from 1996, except for juvenile walleye pollock, which were collected only in 1995 (Fig. 4, Table 3). The dietary trends were similar to those of the pelagic coelenterates. All fish species consumed some of each zooplankton taxon, but juvenile walleye pollock, sandlance, and herring consumed mostly small copepods (45 to $85 \%$ ), while juvenile pink salmon consumed mostly larvaceans (85\%).

\section{Prey selection by pelagic coelenterates and fishes}

Prey selection analyses for pelagic coelenterates provided insight into the trends apparent in the dietary comparisons. All pelagic coelenterate species selected against large ( $>2.5 \mathrm{~mm}$ TL) calanoid copepods (Fig. 5), which were rare in the zooplankton samples (Fig. 2). Selection for small copepods was significantly positive for Aurelia labiata at $60 \%$ of the stations where they were collected. For Pleurobrachia bachei, selection of small copepods was significantly negative at $60 \%$ of their stations, due to the strong positive selection for

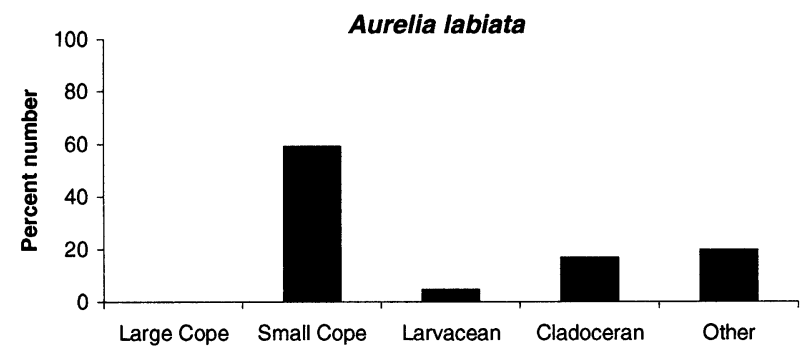

Pleurobrachia bachei

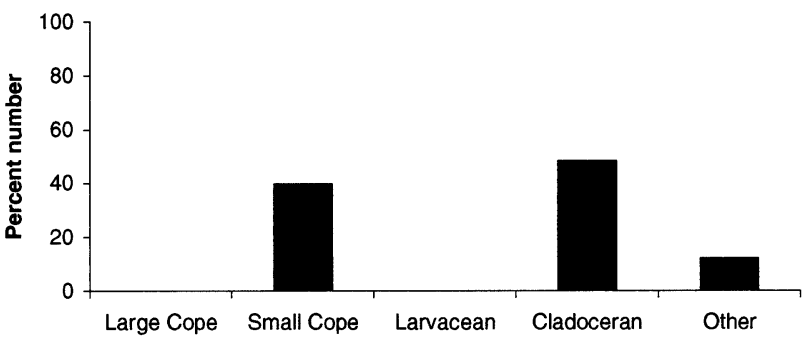

Cyanea capillata
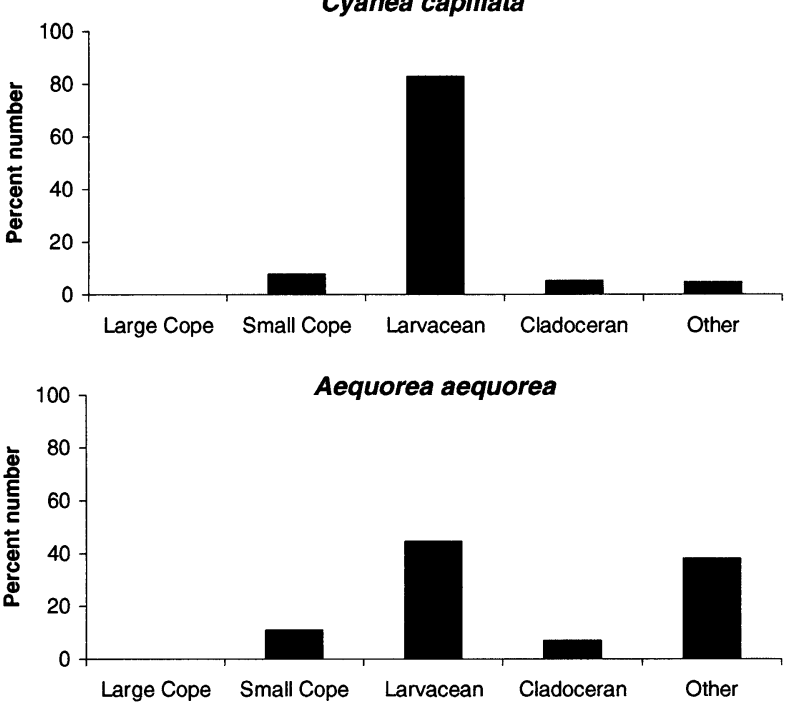

Fig. 3. Aurelia labiata, Pleurobrachia bachei, Cyanea capillata and Aequorea aequorea. Percentage composition of zooplankton prey in the gut contents of medusae and ctenophores in Prince William Sound. All data were from July and August 1997, except those for A. aequorea, which were from July 1998. See Table 3 for dates of collection, number of stations, number of pelagic coelenterates examined, and number of prey

cladocerans. For Cyanea capillata, selection was strong and significantly negative for small copepods and positive for larvaceans at all stations, and positive for cladocerans at most stations. Aequorea aequorea showed relatively weak selection; selection was significantly negative for copepods at $45 \%$ of the stations and signficantly positive for larvaceans at $20 \%$ of the stations. Selection of 'other' prey types, primarily 
Table 3. Numbers of specimens examined, sizes (means $\pm 1 \mathrm{SD}$ ), prey items and stations for gut-content analysis of pelagic coelenterates and forage fishes (Age-0) from Prince William Sound during July and August. All pelagic coelenterate data are from 29 July to 8 August 1997, except those for Aequorea aequorea (14 to 20 July 1998), and all fish data are from 16 to 28 July 1996 , except those for walleye pollock (26 July to 10 August 1995). Walleye pollock: Theragra chalcogramma; Pacific sandlance: Ammodytes hexapterus; Pacific herring: Clupea pallasi; pink salmon: Oncorhynchus gorbuscha

\begin{tabular}{|c|c|c|c|c|}
\hline & Aurelia labiata & Pleurobrachia bachei & Cyanea capillata & Aequorea aequorea \\
\hline No. of pelagic coelenterates & 8 & 57 & 44 & 35 \\
\hline Preserved diameter (mm) & $104 \pm 31$ & $<10$ & $68 \pm 26$ & $55 \pm 19$ \\
\hline No. of prey & 3585 & 116 & 6706 & 315 \\
\hline \multirow[t]{2}{*}{ No. of stations } & 3 & 14 & 16 & 11 \\
\hline & Walleye pollock & Pacific sandlance & Pacific herring & Pink salmon \\
\hline No. of fish & 100 & 110 & 80 & 70 \\
\hline Fork length (mm) & $58 \pm 4$ & $78 \pm 10$ & $41 \pm 7$ & $87 \pm 14$ \\
\hline No. of prey & 10,299 & 5899 & 2162 & 2846 \\
\hline No. of stations & 12 & 15 & 13 & 7 \\
\hline
\end{tabular}

bivalve larvae, was neutral or generally negative for the pelagic coelenterate species.

Of the fish species, 2 showed marked trends in selection, but 2 others did not (Fig. 6). Juvenile walleye pollock showed significant positive selection for large copepods at $50 \%$ of the stations, and for other prey at most stations. Walleye pollock also showed significant negative selection for small copepods at all stations, and significant positive selection for larvaceans and negative selection for cladocerans at about $25 \%$ of the stations. Juvenile pink salmon showed significant negative selection for small copepods and significant positive selection for larvaceans at all stations. In contrast, sandlance and herring were not strongly selective. Prey selection by sandlance was especially weak and mixed for all prey taxa. Herring showed somewhat stronger, but generally weak prey selection.

\section{Dietary overlap among pelagic coelenterates and fishes}

Dietary overlap among pelagic coelenterate species was generally below $60 \%$ (Table 4 ). The greatest dietary overlaps were among species that ate mostly crustaceans, Aurelia labiata and Pleurobrachia bachei $(68 \%)$, and among species that ate mostly larvaceans,

Fig. 4. Walleye pollock Theragra chalcogramma, sandlance Ammodytes hexapterus, herring Clupea pallasi, and pink salmon Oncorhynchus gorbuscha. Percentage composition of zooplankton prey in the gut contents of juvenile fishes in Prince William Sound. All data are from July 1996, except those for walleye pollock (July and August 1995). See Table 3 for dates of collection number of stations, number of fishes examined, and number of prey
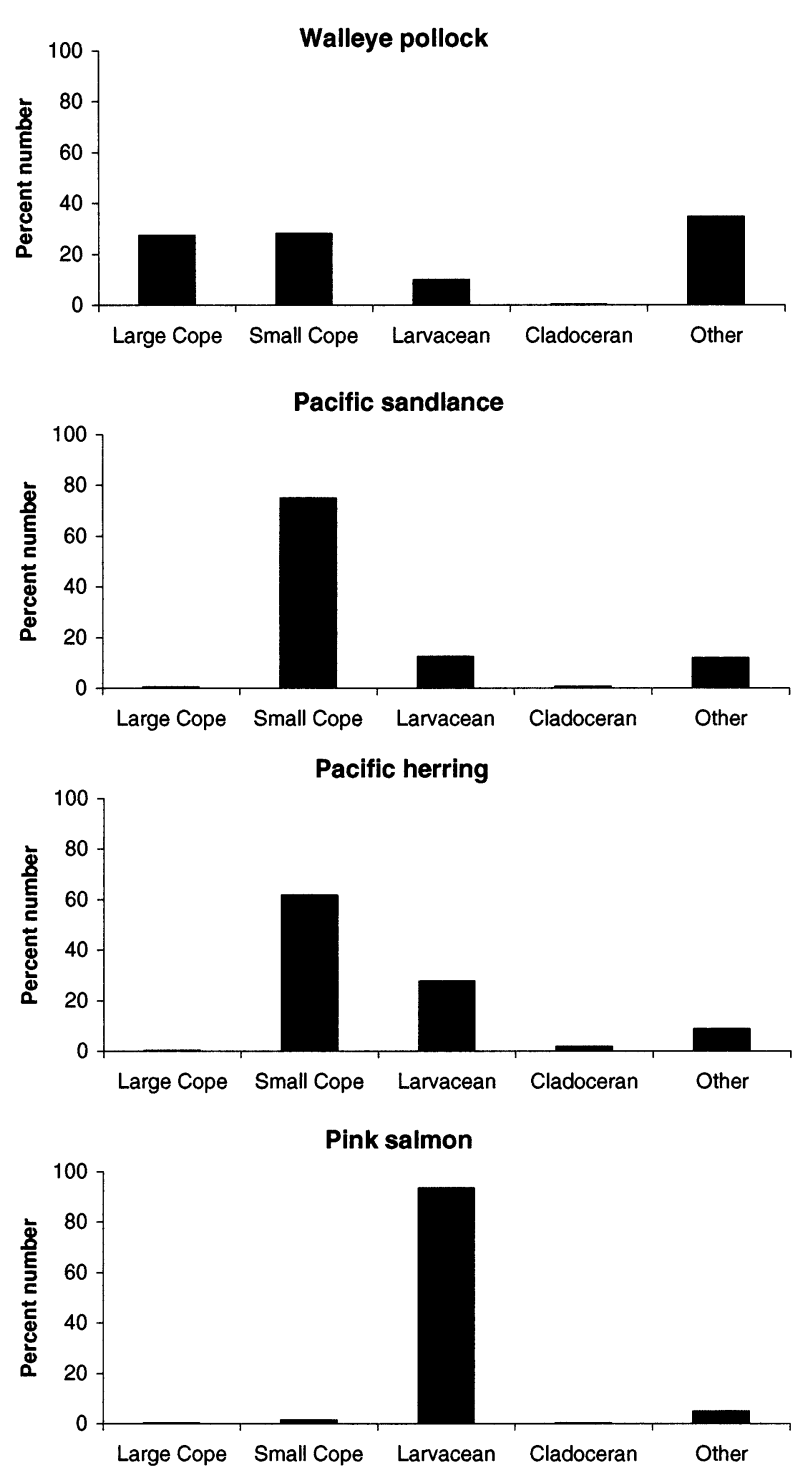

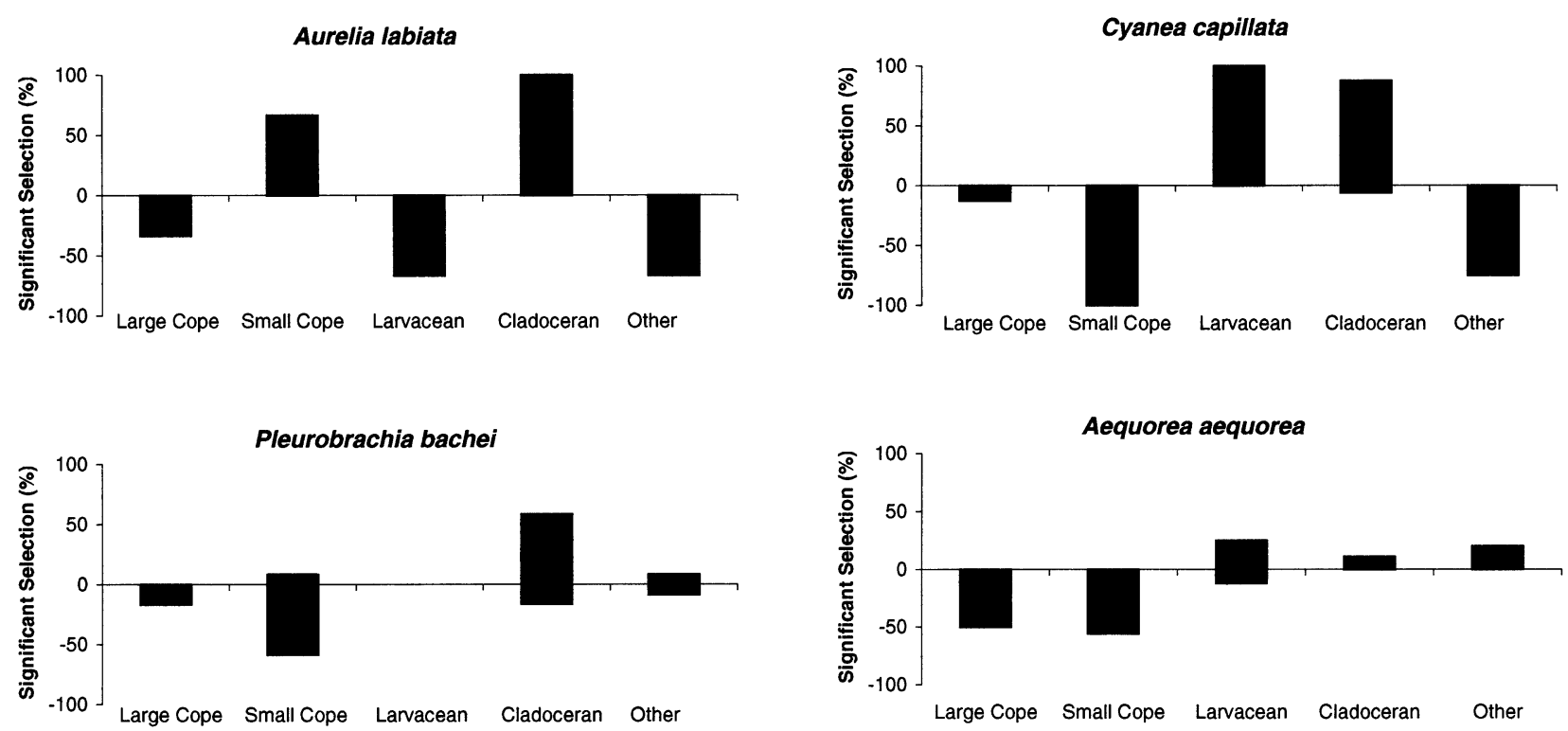

Fig. 5. Aurelia labiata, Pleurobrachia bachei, Cyanea capillata and Aequorea aequorea. Selection of zooplankton prey by medusae and ctenophores in Prince William Sound. Percentages represent the proportions of stations where prey selection was either significantly positive or negative relative to the total number of stations where each species was collected for gut-content analysis. All data were from July and August 1997, except those for A. aequorea, which were from July 1998. See Table 3 for dates of collection, number of stations, number of pelagic coelenterates examined, and number of prey

Cyanea capillata and Aequorea aequorea (62\%). Dietary overlaps among crustacean-eating and larvacean-eating species were low (17 to $49 \%$ ). The average overlap among all pelagic coelenterate species was $41 \pm 21 \%$.

Table 4. Percent diet similarities (PSI) among pelagic coelenterate and among forage fish species (Age-0) during summer in Prince William Sound. Dietary data for pelagic coelenterates are from July and August 1997, except those for Aequorea aequorea (July 1998), and data for fishes are from July 1996, except those for walleye pollock (July and August 1995). Specific names of fishes are given in Table 3 legend

\begin{tabular}{|lc|}
\hline & PSI (\%) \\
\hline Pelagic coelenterates & \\
Aurelia labiata vs Pleurobrachia bachei & 68.4 \\
Aurelia labiata vs Aequorea aequorea & 49.1 \\
Aurelia labiata vs Cyanea capillata & 21.9 \\
Aequorea aequorea vs Pleurobrachia bachei & 29.7 \\
Cyanea capillata vs Aequorea aequorea & 61.8 \\
Cyanea capillata vs Pleurobrachia bachei & 17.4 \\
Forage fishes & \\
95 walleye pollock vs 96 Pacific sandlance & 50.4 \\
95 walleye pollock vs 96 Pacific herring & 47.1 \\
95 walleye pollock vs 96 pink salmon & 16.4 \\
96 Pacific sandlance vs 96 Pacific herring & 83.5 \\
96 Pacific herring vs 96 pink salmon & 34.2 \\
96 sandlance vs 96 pink salmon & 18.9 \\
\hline
\end{tabular}

Dietary overlap among fish species showed similar trends to that for pelagic coelenterates, but overlaps were generally greater (Table 4 ). The greatest overlaps occurred between crustacean-eating species, juvenile walleye pollock, sandlance, and herring (47 to $84 \%$ ). Juvenile pink salmon, which ate mostly larvaceans, showed low dietary similarity with the other fish species (16 to $34 \%$ ). The average overlap among all fish species was $42 \pm 25 \%$.

Dietary similarities among pelagic coelenterate and fish species were greatest among crustacean-eating species and among larvacean-eating species (Table 5). The diets of Aurelia labiata and Pleurobrachia bachei

Table 5. Percent diet similarities (\%) among pelagic coelenterate and forage fish (Age-0) species in Prince William Sound. Dietary data for pelagic coelenterates are from July and August 1997, except those for Aequorea aequorea (July 1998), and data for fishes are from July 1996, except those for walleye pollock (July and August 1995). Specific names of fishes are given in Table 3 legend

\begin{tabular}{|lcccr|}
\hline & $\begin{array}{c}\text { Walleye } \\
\text { pollock }\end{array}$ & $\begin{array}{c}\text { Pacific } \\
\text { sandlance }\end{array}$ & $\begin{array}{c}\text { Pacific } \\
\text { herring }\end{array}$ & $\begin{array}{c}\text { Pink } \\
\text { salmon }\end{array}$ \\
\hline Aurelia labiata & 67.2 & 75.1 & 73.3 & 18.7 \\
Pleurobrachia bachei & 41.1 & 63.4 & 62.0 & 5.3 \\
Cyanea capillata & 34.8 & 33.7 & 50.2 & 78.1 \\
Aequorea aequorea & 55.2 & 35.5 & 48.9 & 59.0 \\
\hline
\end{tabular}



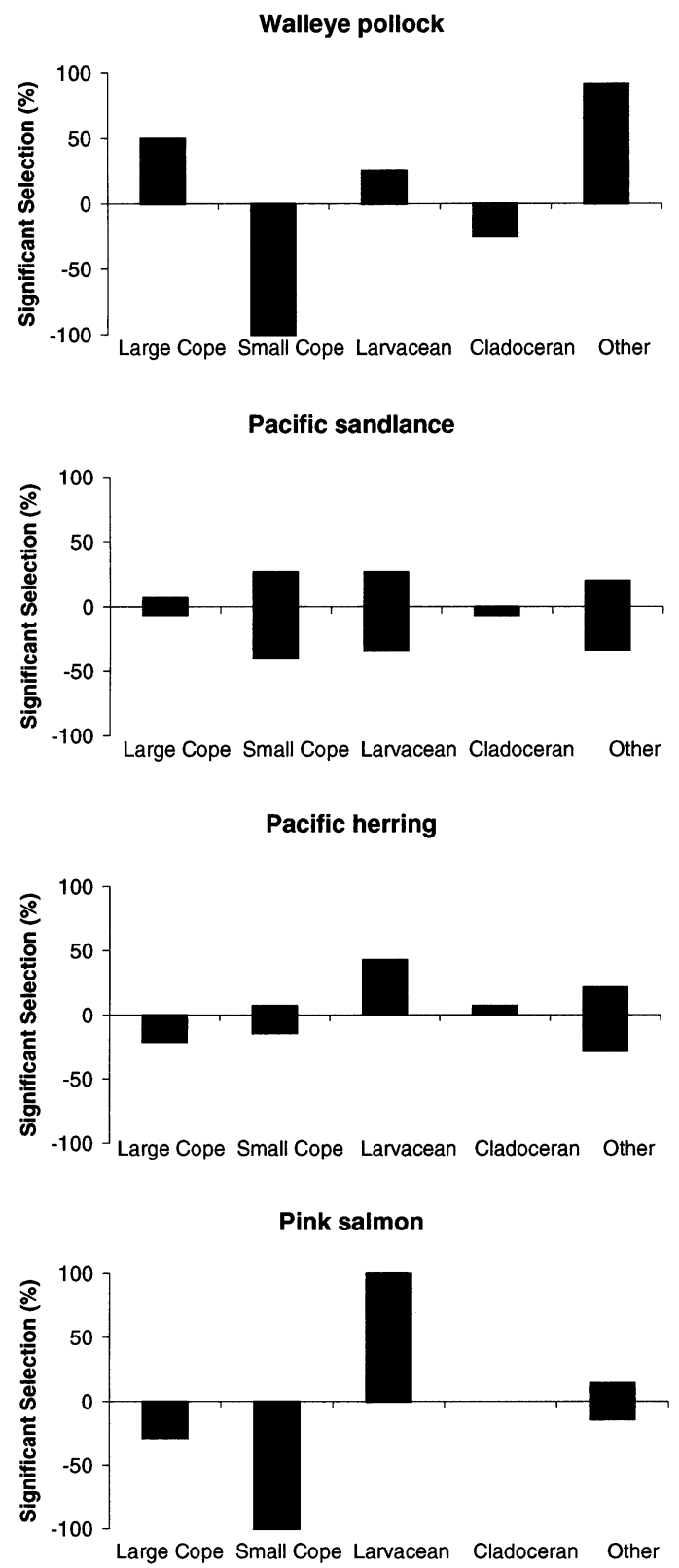

Fig. 6. Walleye pollock Theragra chalcogramma, sandlance Ammodytes hexapterus, herring Clupea pallasi, and pink salmon Oncorhynchus gorbuscha. Selection of zooplankton prey by juvenile (Age-0) fishes in Prince William Sound. Percentages represent the proportions of stations where prey selection was either significantly positive or negative relative to the total number of stations where each species was collected for gut-content analysis. All data are from July 1996, except those for walleye pollock (July and August 1995). See Table 3 for dates of collection, number of stations, number of fish examined, and number of prey

overlapped 67 to 75 and 41 to $63 \%$, respectively, with diets of juvenile walleye pollock, sandlance and herring. The diets of Cyanea capillata and Aequorea aequorea overlapped 78 and $59 \%$, respectively, with diet of juvenile pink salmon. PSI comparisons among all pelagic coelenterate and fish species averaged $50 \pm$ $21 \%$. Thus, dietary overlaps between pelagic coelenterates and fishes were of similar magnitude as overlaps within each group.

\section{DISCUSSION}

The best dietary comparisons among fish and pelagic coelenterate species would be for specimens collected at the same times and locations, but this was not possible in the APEX study. Because zooplankton and predator abundances and distributions vary as much at small spatial and temporal scales as they do at large scales (e.g. Macer 1966, McGurk \& Warburton 1992, Springer 1992, Brodeur \& Wilson 1996, Brodeur et al. 1996, Fritz 1996, Incze et al. 1997, Schweigert 1997, Zheng 1997, Anderson \& Piatt 1999, Foy 2000, Orsi et al. 2000, Stokesbury et al. 2000), and because the predator diets depend, in large part, on the availability of prey, we have taken a general approach to illustrate the degrees of similarity among the diets of pelagic coelenterate and fish predators. We show that the proportions of zooplankton taxa available were very similar in all years, which allowed us to compare diets among different years even though zooplankton densities may have varied among years. The proportional differences observed were due to occasional high abundance of 1 prey type (i.e. bivalve veligers, invertebrate eggs). We minimized the effect of variation by restricting our analyses to single years, as much as possible, and by using zooplankton data from $243 \mu \mathrm{m}$ mesh nets only.

\section{Diets of pelagic coelenterates and fishes}

The diets of the pelagic coelenterates collected in PWS were generally similar to those reported from other locations, with some differences connected with the prey available. Such differences are generally due to the unusually high abundance of an easily captured (e.g. herring larvae) or a poorly digested prey type (e.g. bivalve veligers). For example, dietary differences observed between years in PWS were attributed to differences in the availability of bivalve veligers. Bivalve veligers constituted 0.7 and $12.0 \%$ of mesozooplankton organisms present in 1997 and 1998, respectively, and between 4.6 and $66.4 \%$ of the prey items in Aurelia labiata medusae, and 0.5 and $12.8 \%$ of the prey items in Cyanea capillata medusae in the 2 years. 
The presence of bivalve veligers in the gut contents of medusae and fishes does not mean that they have been killed or digested by the predators. Bivalve larvae have been reported as major components of the diets of several species of scyphomedusae (e.g. Brewer 1989, Larson 1991, Behrends \& Schneider 1995) and some juvenile fishes (e.g. Bailey et al. 1975, Coyle \& Paul 1992, Sturdevant \& Willette 1999); however, whether or not the veligers were digested (open shell, reduced tissue) generally has not been reported. Purcell et al. (1991) showed that $99 \%$ of the bivalve veligers were egested alive by the scyphomedusan Chrysaora quinquecirrha, even after retention in the medusae for up to $7 \mathrm{~h}$. In the present study, $\leq 0.5 \%$ of the bivalve veligers were digested in the preserved gut contents of medusae: Aurelia labiata (10 of 9398 veligers), Cyanea capillata (2 of 413 veligers), and Aequorea aequorea ( 0 of 52 veligers). Mollusc veligers appeared to be undigested in northern anchovy and herring larva gut contents (summarized in Checkley 1982). Similarly, bivalve veligers were usually closed in the fish gut contents (Sturdevant unpubl. data). We conclude that the closed shells of captured bivalve veligers may protect them from digestion by these predators. In contrast, Mnemiopsis leidyi ctenophores, which use ciliary currents during digestion, did digest the bivalve veligers (Purcell et al. 1991). We do not know how broadly this indigestibility of bivalves applies across various predator taxa, or if gastropod veligers and thecosome pteropods are similarly protected from digestion.

We did not adjust gut-content data for possible differences in digestion rates of the various prey taxa by pelagic coelenterates or fishes. Adjusting for digestion time is not typical in studies using dietary data for jellyfish or for fishes. For Aurelia labiata and Cyanea capillata medusae, small copepods and cladocerans were digested in about $2 \mathrm{~h}$, and larvaceans in about $1 \mathrm{~h}$ (Purcell unpubl. data). Data on digestion times of these prey by the forage fish species in this study are not available, to our knowledge. Sutela \& Huusko (2000) found that crustacean prey were more resistant to digestion by fish larvae than soft-bodied prey (rotifers). Therefore, we expect that the trends in our study would be similar for both predator groups. Because selection patterns were strong when comparing crustacean and larvacean prey, and these differences in digestion rates would generally enhance the differences rather than reduce them, we believe our conclusions would be unchanged.

During July 1997 in PWS, Aurelia labiata medusae contained $75 \%$ small crustaceans and $10 \%$ larvaceans. The diet of this species has not been determined before; however, the diet of its congener, A. aurita, similarly contains a mixture of plankton organisms.
The diet of $A$. aurita sometimes is dominated by specific prey types that occur in great abundance at a sampling location or season. For example, Möller (1980) reported great numbers of herring larvae in the spring diet of A. aurita medusae in Kiel Bight, Germany; their summer diet from the same location, however, contained no fish larvae, but $25 \%$ copepods and $75 \%$ mollusc larvae (Behrends \& Schneider 1995).

Our study and others show that the diet of Pleurobrachia bachei ctenophores consistently contains 97 to $98 \%$ crustaceans, with the percentages of copepods, cladocerans, and other prey varying with availability (Hirota 1974, Larson 1987).

Unlike the previous 2 species, the diet of Cyanea capillata medusae can contain large amounts of softbodied prey. Again, the dietary composition depends on the prey available. For example, the diet composition of $C$. capillata diet varied from 3 to $22 \%$ copepods, 3 to $75 \%$ cladocerans, 3 to $80 \%$ larvaceans, 0 to $34 \%$ hydromedusae, and 2 to $63 \%$ ichthyoplankton on 7 sampling dates in Port Phillip Bay, Australia (Fancett 1988), and varied seasonally as different prey became available in the Niantic estuary, USA (Brewer 1989). In July 1997 in PWS, C. capillata consumed an average of $70 \%$ larvaceans and only $20 \%$ crustacean prey. We also observed C. capillata feeding on Aurelia labiata and Aequorea aequorea medusae in 1999. Predation by $C$. capillata on Aurelia aurita medusae and ctenophores is believed to be an important source of food for this species (Båmstedt et al. 1997).

The diet of Aequorea aequorea medusae, which has not been previously reported, contained a high percentage of soft-bodied prey ( $>40 \%$ larvaceans) and low percentages of crustaceans $(<20 \%$ total $)$. The diet of its congener, A. victoria, from Vancouver Island, British Columbia, varied with prey abundance, but also consistently contained high percentages of softbodied prey, like fish larvae ( 2 to $48 \%$ ), larvaceans (35\%), and other gelatinous species (3 to $13 \%$ ), but generally low percentages of crustacean prey (14 to $49 \%$ ) (Purcell 1989).

The zooplanktivorous diet and predominance of calanoid copepods in 3 of the forage species' diets that we report generally agree with other workers' observations. Juvenile pollock in the North Pacific feed on small calanoids and larval euphausiids in summer, shifting to larger prey, such as large calanoids and larger euphausiids, with growth (e.g. Kamba 1977 , Krieger 1985, Grover 1991, Kendall \& Nakatani 1992, Brodeur 1998). Larvaceans can be important prey in some geographic areas (Merati \& Brodeur 1996), and epibenthic prey may increase as zooplankton stocks diminish and fishes become demersal in fall and winter (Rogers et al. 1979, Simenstad et al. 1979, Krieger 1985, Nakatani 1988). 
For Pacific sandlance and congeners, multiple stages of small and large calanoids prevail in the diets, with diverse other taxa (e.g. barnacle larvae, larvaceans, euphausiids, gammarid amphipods) important at times such as late autumn, when calanoids are not abundant (Sekiguchi et al. 1974, Meyer et al. 1979, Craig 1987, Monteleone \& Peterson 1986, Blackburn \& Anderson 1997).

Diets of Age-0 Pacific herring consist of predominantly calanoid copepods in spring and summer (Haegele 1997, Foy \& Norcross 1999). Prey include both large and small copepods, crustacean larvae (e.g. decapod zoeae and barnacle larvae), invertebrate eggs, chaetognaths, larvaceans, mysids, amphipods and euphausiids (Sherman \& Perkins 1971, Harris \& Hartt 1977, Simenstad et al. 1979, Coyle \& Paul 1992). Change from predation on calanoids by younger herring to macrozooplankton such as euphausiids and hyperiids by older fish has also been reported (Wailes 1936, Lassuy 1989, Last 1989, Haegele 1997). For juvenile herring in PWS, the relative proportions of large and small calanoid prey varied both seasonally and spatially, but proportionally more biomass tended to come from large calanoids and a combination of malacostraca, hyperiids and euphausiids by late summer (Foy \& Norcross 1999, Sturdevant \& Willette 1999).

The mono-specific diet (larvaceans) of juvenile pink salmon in our study is somewhat unusual, but was also observed by Healey (1991). Larvaceans are common in juvenile pink salmon diets, but small crustaceans typically contribute most prey biomass (e.g. Manzer 1969, Bailey et al. 1975, Cooney et al. 1981, Sturdevant et al. 1996, Sturdevant \& Willette 1999). Throughout the spring, pink salmon prey on both pelagic and epibenthic taxa, including small and large calanoids, cyclopoids and harpacticoids, with lesser amounts of other small taxa such as cumaceans, cladocerans, barnacle and bivalve larvae, and pteropods; by late summer, more of their prey tend to come from larger specimens of these taxa, larger crustacean taxa (especially hyperiid amphipods and euphausiids), or fishes (Karpenko \& Piskunova 1985, Perry et al. 1996, Haegele 1997, Moulton 1997, Landingham et al. 1998).

\section{Prey selection by pelagic coelenterates and fishes}

Most species of medusae and ctenophores have broad diets in which crustacean prey predominate, but prey selection typically occurs. Because these predators do not actively attack prey, prey selection depends on various characteristics of the predators and prey (reviewed in Purcell 1997). Prey selection analyses theoretically do not vary with relative prey abundances (Pearre 1982); hence they are more consistent than dietary analysis and enable general patterns of feeding to emerge. The selection analyses here confirm the patterns seen among diets of pelagic coelenterate and fish predators.

The prey electivities presented here show similar trends to those calculated previously for congenors of Aurelia labiata and Aequorea aequorea, and for Pleurobrachia bachei and Cyanea capillata. Only Sullivan et al. (1994) reported electivity indices for Aurelia aurita, which showed significant positive selection for hydromedusae on $100 \%$ of 9 dates and for calanoid copepods and barnacle nauplii on $14 \%$ of 7 dates, and significant negative selection for copepods on $28 \%$ of 7 dates and copepod nauplii on $100 \%$ of 4 dates. For $A$. labiata in PWS, we found significant positive selection for small copepods ( $65 \%$ of stations) and cladocerans $(100 \%)$ and significant negative selection for larvaceans $(75 \%)$ and other prey (primarily bivalve larvae).

In California waters, prey selection by Pleurobrachia bachei was positive for small copepods (Acartia tonsa and Labidocera trispinosa) and cladocerans (Evadne spp.), but was negative for the cladoceran Penilia avirostris and chaetognaths (Hirota 1974). We obtained opposite results, with negative selection for small copepods and positive selection for cladocerans; however, we did not distinguish between the 2 species of cladocerans present (Evadne sp. and Podon leukarti) in our analysis.

Cyanea capillata in PWS showed prey selection similar to that in Port Phillip Bay, Australia, where selection was positive for amphipods, decapods, crab zoea, Podon spp. and larvaceans, and negative for Evadne spp. and for all copepod taxa. In PWS, C. capillata showed strong selection against copepods (significant in $100 \%$ of collections), and strong selection for larvaceans $(100 \%)$ and cladocerans (Evadne sp. and Podon leukarti combined).

We report the same patterns of prey selection here for Aequorea aequorea as were reported by Purcell (1989) for Aequorea victoria, which showed negative selection for copepods and other crustaceans, and positive selection for soft-bodied organisms, such as larvaceans. Other gelatinous species and ichthyoplankton prey that were highly preferred by $A$. victoria were not abundant in the plankton samples taken in July in PWS, and were not found in the gut contents of $A$. aequorea then.

The patterns of prey selection that we observed for the fish species generally agree with previous reports. Juvenile pollock were selective planktivores at several young stages examined in various areas. In Japanese waters in April, late larvae selected Pseudocalanus minutus rather than Oithona spp. from among small calanoids, and in May the large calanoid Eucalanus 
bungii and euphausiid juveniles were selected (Kamba 1977). In the Gulf of Alaska in September, juvenile pollock selected decapod larvae, euphausiids and fish larvae; they strongly avoided copepods relative to their abundance in plankton, taking only the late stages of the large species Calanus marshallae and Metridia spp. (Brodeur 1998). Prey size generally increased, but minimum prey sizes did not change with increasing fish size (Brodeur 1998). Although we used data from a $303 \mu \mathrm{m}$ mesh net for the proportions of zooplankton taxa available to pollock in 1995 instead of $243 \mu \mathrm{m}$ mesh samples used for all other predator species, Sturdevant \& Willette (1999) showed that the percentage composition of principal zooplankton taxa did not differ between 243 and $303 \mu \mathrm{m}$ mesh sizes; thus, we required no adjustment in calculations of prey selection.

The prey selection of the Pacific sandlance Ammodytes hexapterus had not been examined before these studies in PWS (Sturdevant \& Willette 1999, this study). However, prey selection has been reported for its congeners. In Age-0 Ammodytes personatus, smaller individuals selected cladoceran over calanoid species, and targeted Evadne spp. over the more abundant Podon spp.; larger individuals selected calanoids, and targeted species of Acartia and Calanus over the more abundant Paracalanus and Oithona (Sekiguchi et al. 1974). At the same time, however, the predominant prey of this sandlance tracked seasonal changes in the densities of Acartia and Paracalanus species from March to June (Sekiguchi 1977). The northern sandlance Ammodytes dubius preferred the larger zooplankters in plankton tows, large calanoids Calanus marshallae, euphausiids and polychaete larvae, but was limited in its ability to prey on the larger euphausiid individuals (Scott 1973).

Herring feed selectively with respect to both particle size and type; selection varies with particle visibility, prey escape ability and larval feeding experience (Checkley 1982, Munk 1992, Tsuda et al. 1998), as well as the prey taxa available by region. For example, Pacific herring up to $33 \mathrm{~mm}$ long selected Acartia longiremis females and rarely consumed the larger calanoids Pseudocalanus newmani, Neocalanus plumchrus or Eucalanus bungii (Tsuda et al. 1998). Baltic herring smaller than $49 \mathrm{~mm}$ in length selected cladocerans rather than calanoids, but larger juveniles selected the calanoid Acartia sp. over Pseudocalanus sp. (Arrhenius 1996). In contrast, Atlantic herring larvae in western Scotland waters did not select Acartia sp., and preferred copepodites of Oithona sp. over those of Pseudocalanus sp. as fish size increased (Checkley 1982). In the North Sea, small larvae selected Acartia tonsa while larger larvae selected Calanus finmarchicus (Munk 1992). However, young herring preferred copepods of constant relative size
(Checkley 1982, Munk 1992) and, like pollock, consumed prey in a narrower size range than they were capable of. Non-selective filter-feeding on very small, highly abundant prey like invertebrate eggs, which we pooled in 'other,' has been shown for both pollock (e.g. Grover 1991) and sandlance (Scott 1973).

When available, large calanoids such as species of Metridia and Calanus /Neocalanus were selected even by recently emerged pink salmon fry (Cooney et al. 1981). In summer, larger juvenile pink salmon selected for macroplankton (Willette et al. 1997); they avoided small copepods and selected crab zoeae, large calanoids, euphausiids, hyperiids, and larvaceans (Karpenko \& Piskunova 1985, Healey 1991, Landingham et al. 1998). However, a size-related shift to larger prey is not always evident for juvenile pink salmon (Healey 1991).

\section{Dietary overlap among pelagic coelenterates and fishes}

The dietary overlap among different pelagic coelenterate species has not been examined previously. Prior emphasis has been on distinguishing dietary patterns among broad taxonomic categories (e.g. Purcell \& Mills 1988, Purcell 1997). We demonstrate here that in addition to showing differences in selectivity, with some species utilizing mainly crustacean prey and other species utilizing high proportions of soft-bodied prey, diets of the co-occurring species overlapped by an average of $41 \%$ when compared mainly within the same year. Comparisons between years for jellyfish collected from the same stations in 1997 and 1998 showed 42 and $48 \%$ dietary overlap within species for Aurelia labiata and Cyanea capillata, respectively, due to the high proportions of bivalve veligers in the diets in 1998.

The dietary overlaps among these fish species have rarely been examined, although several reports on food webs of the Pacific Northwest include descriptions of their food habits. In Puget Sound/Strait of Juan de Fuca, Simenstad et al. (1979) classified all 4 species as pelagic planktivores, but Pacific sandlance, Pacific herring and pink salmon belonged to the same neritic assemblage, while juvenile walleye pollock was assigned to a shallow sublittoral assemblage. This suggests that the greatest potential for dietary overlap occurs among the species pairs not including pollock, although the authors felt that sandlance feeding was more specialized than herring feeding (Simenstad et al. 1979). Similarities among the species were also shown by studies in the nearshore zone of Kodiak Island (Harris \& Hartt 1977, Rogers et al. 1979). In both spring and summer, pollock, sandlance and juvenile 
pink salmon up to $150 \mathrm{~mm}$ in length fed on zooplankton, principally calanoids, and on epibenthic crustaceans, while herring ate mainly calanoids (Harris \& Hartt 1977). In a Strait of Georgia study (Haegele 1997), planktivorous juvenile salmon generally did not target copepods, unlike herring; however, Tsuda et al.'s (1998) laboratory study showed that young chum salmon, which often have diets very similar to those of pink salmon (e.g. Bailey et al. 1975, Willette et al. 1997, Landingham et al. 1998), preferred larger calanoids than did herring. McGurk et al. (1992) inferred competition between sandlance and herring larvae feeding on the same types of prey with similar lengths but different widths. A comparison of forage species diets in summer 1994 in PWS (Willette et al. 1997) used cluster analysis to show greater similarity between juvenile herring and pollock diets than between either of these species and sandlance diet, and pink salmon diet was not similar to any of them. The behavioral mechanisms for prey-partitioning among these co-occurring fishes have not been investigated.

The degree of dietary overlap varies between pairs of zooplanktivorous fish species. Overlap can change seasonally or when prey becomes limited, and can depend on relative predator sizes, densities, or spatial proximity (e.g. Sekiguchi 1977, Cooney et al. 1981, Perry et al. 1996, Haegele 1997, Foy \& Norcross 1999, Sturdevant \& Willette 1999). For example, dietary overlap among juvenile pollock, sandlance, herring and pink salmon (aged 0 to $2 \mathrm{yr}$ ) in PWS ranged from 32 to $81 \%$ between May and November 1994 (Sturdevant \& Willette 1999). The months of greatest dietary overlap differed among the species pairs. Herring diet overlap with pollock exceeded $50 \%$ in June and November, with pink salmon in July, and with sandlance in May and September; pink salmon overlap with pollock never exceeded $50 \%$, while pink salmon overlap with sandlance exceeded $50 \%$ only in June; pollock overlap with sandlance exceeded $50 \%$ in July. Thus, June and July were the only months with high dietary overlap between more than 1 pair of species. Sturdevant \& Willette 1999 demonstrated variation in diet overlap according to the degree of spatial overlap between species; dietary overlap between sandlance and herring declined in summer from $>70 \%$ among allopatric fish to $<50 \%$ among sympatric fishes. This decline in similarity and changes in prey composition indicated prey-partitioning. Willette et al. (1997), however, showed an increase in similarity between diets of herring and pollock in late summer 1994 from $27 \%$ for allopatric fishes to $71 \%$ for sympatric fishes, while in 1995 diet overlap of both summer allopatric and autumn sympatric pollock and herring were high (Sturdevant \& Willette 1999). We found species' diets to be similar among years when comparisons were possible. The diets of sandlance collected in 1995 and 1996 overlapped by only $36 \%$ due to greater utilization of invertebrate eggs in 1995 (Sturdevant et al. 1996, Sturdevant \& Willette 1999). The diets of herring in 1995 and 1996 overlapped by $76 \%$.

The diets of pelagic coelenterates and zooplanktivorous fishes overlapped substantially in PWS. The greatest dietary overlaps occurred among species that ate mostly crustacean prey and among species that ate mostly larvaceans. The degrees of dietary overlap probably vary both spatially and temporally, because diet composition and food quantity differ with the prey taxa available and the amount of food present, respectively (e.g. Perry et al. 1996). Although the gut contents of pelagic coelenterates and fishes could not be collected in the same years, the zooplankton populations showed great similarity (mean $85 \%$ ) among all regions and years, allowing us to make dietary comparisons. Even though the dietary overlaps among pelagic coelenterate species (mean $41 \%$ ) and fish species (mean $42 \%$ ) were calculated mostly within a season, dietary overlaps among pelagic coelenterates and fishes collected from different years showed an even higher average $(50 \%)$. Greater dietary overlaps among pelagic coelenterates and fishes might be expected if all data were collected from the same years and locations. For example, dietary overlap of pollock and sandlance in 1995 was $78 \%$ compared with $50 \%$ when data from 1995 and 1996 were compared, and the dietary overlap of pollock and herring in 1995 was $71 \%$, compared with $47 \%$ in 1995 versus 1996 .

The potential for competition for zooplankton prey among pelagic coelenterates and fishes is very difficult to assess. Whether competition would occur depends on the extent of the spatial, depth and temporal cooccurrence of the various predators considered here, as well as their abundances and consumption rates of zooplankton and the density and production rates of the zooplankton. Determination of those parameters was beyond the scope of the present paper, but will be addressed in a future paper. In addition to the gelatinous species considered here, numerous small zooplanktivorous hydromedusae and chaetognaths also occur in PWS (R. T. Cooney et al. unpubl. data), and would increase the potential for competition for prey among pelagic coelenterates and fishes. Previous publications on the carrying capacity of PWS have not considered seasonal dietary changes or multi-species interactions (Cooney 1993).

Populations of the pelagic coelenterate species considered here develop in June to July and persist only until October, which limits the potential for competition with fishes to that time period. During the period that pelagic coelenterates and fish co-occur in PWS, a number of mechanisms act to limit competitive inter- 
actions. For example, at the time of this study, the majority of pink salmon had exited from PWS to the Gulf of Alaska (Cooney 1993), a migration possibly triggered by declining abundance and diversity of optimally sized prey (Simenstad \& Salo 1982, Healey 1991). Pink salmon diets were least similar to those of other fish species', and overlapped substantially with half of the pelagic coelenterate species. Their exodus from PWS followed several months of moderate diet overlap (Sturdevant \& Willette 1999) between predominant fish species, and limited predation on common prey at that time to the year-round residents such as the other 3 forage species. Thus, the number of potential competitors decreases as food stocks decline. The more passively feeding pelagic coelenterates are less likely to use the same mechanisms as the fish species to avoid competition, such as switching to epibenthic prey, as for herring, pollock and sandlance (e.g. Krieger 1985, Craig 1987, Foy \& Norcross 1999), partitioning food by depth, as for herring (e.g. Coyle \& Paul 1992), or feeding at different times of day (Sturdevant \& Willette 1999).

\section{Co-occurrence of jellyfish and fishes in PWS}

We present preliminary qualitative evidence to illustrate that the fishes and the large jellyfish species do overlap in space and time in PWS. Untargeted sets of an anchovy seine $250 \mathrm{~m}$ long by $34 \mathrm{~m}$ deep with a $25 \mathrm{~mm}$ stretch mesh were made during 1 to 22 July 1999 at the same stations in PWS as in 1997 and 1998. Both jellyfish and fishes were sorted by species and counted only in 1998 and 1999, but fish data are unavailable to us for 1998. Aurelia labiata, Cyanea capillata, and Aequorea aequorea occurred with juvenile walleye pollock and with juvenile pink salmon in 98 to $100 \%$ of the seine sets in which the jellyfish were collected, respectively (Table 6). The percentages of jellyfish collected with herring (35 to $39 \%$ ) and sandlance (14 to $15 \%$ ) were much lower. These fish species spend the majority of their lives in shoals, and aggregate more or less tightly, depending on whether or not they are feeding (Hobson 1986, Robinson \& Pitcher 1989). They were not targeted in this sampling, and were probably not collected in purse seine hauls because of their orientation along beaches and because sandlance readily escaped through the seine mesh. A. labiata occurred in 41 to $50 \%$ of the seine sets in which the 4 fish species were collected, but $C$. capillata and $A$. aequorea occurred in 94 to $100 \%$ of the sets (Table 6). No seine set contained only jellyfish or only fishes. Similarly, in July 1996, A. labiata and herring were more abundant and pollock less abundant than in 1999 , and 20 to $25 \%$ of seine sets that targeted on fish schools also contained jellyfish (Purcell et al. 2000). Additionally, juvenile walleye pollock were observed by underwater video to be associated with aggregations of A. labiata in 1996 and with individual C. capillata in 1999 (Purcell et al. 2000). Clearly, the jellyfish and fish species included in this study overlap spatially and temporally and utilize the same foods in PWS.

Acknowledgements. We thank L. J. Haldorson, J. Boldt, L. B. Hulbert, M. Auburn-Cook, R. Bailey, S. Keegan, C. Coon, A. L. J. Brase, M. Ewing, D. A. Nemazie, K. Black, M. Leonard, J. Mooney and J. T. Thedinga for help in field sampling, and L. B. Hulbert, M. Auburn-Cook, R. Bailey, S. Keegan, C. Coon, A. L. J. Brase, K. Black and M. Leonard for sample and data analyses. T. C. Shirley collected zooplankton samples that we analysed in 1997 and 1998. We thank D. C. Duffy, L. J. Haldorsen, T. C. Shirley, B. Wright and D. A. Nemazie for making it possible for pelagic coelenterate samples to be collected during APEX cruises in 1997. This research was funded by the 'Exxon Valdez' Oil Spill Trustee Council as part of the Alaska Predator Ecosystem eXperiment (APEX Projects 95163C, 96163C, 97163A, 98163A, 98163S, and 99163S). UMCES contribution No. 3372.

\section{LITERATURE CITED}

Anderson PJ, Piatt JF (1999) Community reorganization in the Gulf of Alaska following ocean climate regime shift. Mar Ecol Prog Ser 189:117-123

Arai MN (1988) Interactions of fish and pelagic pelagic coelenterates. Can J Zool 66:1913-1927

Arrhenius F (1996) Diet composition and food selectivity of 
0-group herring (Clupea harengus L.) and sprat (Sprattus sprattus (L.)) in the northern Baltic Sea. ICES J Mar Sci 53: $701-712$

Ates RML (1988) Medusivorous fishes, a review. Zool Meded (Leiden) 62:29-42

Bailey JE, Wing BL, Mattson CR (1975) Zooplankton abundance and feeding habits of fry of pink salmon, Oncorhynchus gorbuscha, and chum salmon, Oncorhynchus keta, in Traitors Cove, Alaska, with speculations on the carrying capacity of the area. Fish Bull 73:846-861

Bailey KM, Houde ED (1989) Predation on eggs and larvae of marine fishes and the recruitment problem. Adv Mar Biol 25:1-83

Båmstedt U, Ishii H, Martinussen MB (1997) Is the scyphomedusa Cyanea capillata (L.) dependent on gelatinous prey for its early development? Sarsia 82:269-273

Behrends G, Schneider G (1995) Impact of Aurelia aurita medusae (Cnidaria, Scyphozoa) on the standing stock and community composition of mesozooplankton in the Kiel Bight (western Baltic Sea). Mar Ecol Prog Ser 127:39-45

Blackburn JE, Anderson PJ (1997) Pacific sandlance growth, seasonal availability, movements, catch variability, and food in the Kodiak-Cook Inlet area of Alaska. In: Mecklenburg CW (ed) Forage fishes in marine ecosystems. University of Alaska, Fairbanks, p 409-426 (Alsk Sea Grant Coll Prog Rept No. 97-01)

Brewer RH (1989) The annual pattern of feeding, growth and sexual reproduction in Cyanea (Cnidaria: Scyphozoa) in the Niantic River Estuary, Connecticut. Biol Bull 176: 272-281

Brodeur RD (1998) Prey selection by age-0 walleye pollock (Theragra chalcogramma) in nearshore waters of the Gulf of Alaska. Environ Biol Fish 51:175-186

Brodeur RD, MT Wilson (1996) A review of the distribution, ecology and population dynamics of age-0 walleye pollock in the Gulf of Alaska. Fish Oceanogr 5(Suppl 1):148-166

Brodeur RD, Frost BW, Hare SR, Francis RC, Ingraham WJ Jr (1996) Interannual variations in zooplankton biomass in the Gulf of Alaska, and covariation with California Current zooplankton biomass. Calif Coop Ocean Fish Invest Rep 37:80-99

Checkley DM (1982) Selective feeding by Atlantic herring (Clupea harengus) larvae on zooplankton in natural assemblages. Mar Ecol Prog Ser 9:245-253

Cooney RT (1993) A theoretical evaluation of the carrying capacity of Prince William Sound, Alaska, for juvenile Pacific salmon. Fish Res 18:77-87

Cooney RT, Urquhart D, Barnard D (1981) The behavior, feeding biology and growth of hatchery-released pink and chum salmon fry in Prince William Sound, Alaska. Alask Sea Grant Rep Fairbanks 81-5:1-114

Coyle KO, Paul AJ (1992) Interannual differences in prey taken by capelin, herring, and red salmon relative to zooplankton abundance during the spring bloom in a southeast Alaskan embayment. Fish Oceanogr 1:294-305

Craig P (1987) Forage fishes in the shallow waters of the north Aleutian Shelf. In: Allen MJ, Ware RR (eds) Forage fishes of the southeastern Bering Sea. Conference proceedings. US Department of the Interior, Minerals Management Service, Anchorage, p 49-54 (OCS Study MMS 867-0017)

Dawson MN, Martin LE (2001) Geographic variation and ecological adaptation in Aurelia (Scyphozoa, Semaeostomeae): some implications from molecular phylogenetics. Hydrobiologia (in press)

Fancett MS (1988) Diet and prey selectivity of scyphomedusae from Port Phillip Bay, Australia. Mar Biol 98: 503-509
FAO (1999a) FAO yearbook fishery statistics: capture production. FAO Fish Ser 52(84)1997:1-705

FAO (1999b) FAO yearbook fishery statistics: commodities. FAO Fish Ser 53(85)1997:188

Field LJ (1988) Pacific sand lance, Ammodytes hexapterus, with notes on related Ammodytes species. In: Wilimovsky NJ, Incze LS, Westrheim SJ (eds) Species synopses: life histories of selected fish and shellfish of the northeast Pacific and Bering Sea. Washington Sea Grant WSG 88-2. University of Washington, Seattle, p 15-33

Foy RJ, Norcross BL (1999) Spatial and temporal variability in the diet of juvenile Pacific herring (Clupea pallasi) in Prince William Sound, Alaska. Can J Zool 77:1-10

Foy RJ (2000) Juvenile Pacific herring (Clupea pallasi) feeding ecology in Prince William Sound, Alaska. PhD dissertation, University of Alaska, Fairbanks

Fritz LW (1996) Juvenile walleye pollock, Theragra chalcogramma, bycatch in commercial groundfish fisheries in Alaskan waters. NOAA Tech Rep NMFS 126:179-195

Grant US, Higgens DF (1910) Reconnaissance of the geology and mineral resources of Prince William Sound, Alaska. Bull US Geol Surv 443:1-89

Grover JJ (1991) Trophic relationship of age-0 and age-1 walleye pollock Theragra chalcogramma collected together in the eastern Bering Sea. Fish Bull 89:719-722

Haegele CW (1997) The occurrence, abundance and food of juvenile herring and salmon in the Strait of Georgia, British Columbia in 1990 to 1994. Can Man Rep Fish Aquat Sci 2390:1-124

Haldorson L, Shirley T, Coyle K, Thorne R (1997) Forage species studies in Prince William Sound. In: Duffy DC (ed) Exxon Valdez oil spill restoration project annual report (Restoration Project 96163A). University of Alaska, Anchorage, AK, p 1-93

Haldorson L, Shirley T, Coyle K (1998) Forage species studies in Prince William Sound. In: Duffy DC (ed) Exxon Valdez oil spill restoration project annual report (Restoration Project 97163A). University of Alaska, Fairbanks, Anchorage, AK, p 15-49

Harbison GR (1993) The potential of fishes for the control of gelatinous zooplankton. Int Counc Explor Sea Comm Meet 1993/L:74:1-10

Harris CK, Hartt AC (1977) Assessment of pelagic and nearshore fish in three bays on the east and south coasts of Kodiak Island, Alaska. Fish Res Inst Final Rept FRIUW-7719. University of Washington, Seattle, p 483-688)

Healey MC (1991) Diets and feeding rates of juvenile pink, chum, and sockeye salmon in Hecate Strait, British Columbia. Trans Am Fish Soc 120:303-318

Hirota J (1974) Quantitative natural history of Pleurobrachia bachei in La Jolla Bight. Fish Bull 72:295-335

Hobson ES (1986) Predation on the Pacific sand lance, Ammodytes hexapterus (Pisces: Ammodytidae), during the transition between day and night in southeastern Alaska. Copeia 1986:223-226

Incze LS, Siefert DW, Napp JM (1997) Mesozooplankton of Shelikof Strait, Alaska: abundance and community composition. Cont Shelf Res 17:287-305

Juanes F (1994) What determines prey size selectivity in piscivorous fishes? Belle W Baruch Libr. Mar Sci 18:79-100

Kamba M (1977) Feeding habits and vertical distribution of walleye pollock, Theragra chalcogramma (Pallas), in early life stage in Uchiura Bay, Hokkaido. Spec Vol Res Inst North Pac Fish Hokkaido Univ Fac Fish, p 175-197

Karpenko VI, Piskunova LV (1985) Importance of macroplankton in the diet of young salmons of the genus Oncorhynchus (Salmonidae) and their trophic relation- 
ships in the southwestern Bering Sea. J Ichthyol 24: 98-106

Kendall AW, Nakatani T (1992) Comparisons of early-lifehistory characteristics of walleye pollock Theragra chalcogramma in Shelikof Strait, Gulf of Alaska, and Funka Bay, Hokkaido, Japan. Fish Bull 90:129-138

Krieger KJ (1985) Food habits and distribution of first-year walleye pollock, Theragra chalcogramma (Pallas), in Auke Bay, southeastern Alaska. MS thesis, University of Alaska, Juneau

Landingham JH, Sturdevant MV, Brodeur RD (1998) Feeding habits of juvenile Pacific salmon in marine waters of southeastern Alaska and northern British Columbia. Fish Bull 96:285-302

Larson RJ (1987) Trophic ecology of planktonic gelatinous predators in Saanich Inlet, British Columbia: diets and prey selection. J Plankton Res 9:811-820

Larson RJ (1991) Diet, prey selection and daily ration of Stomolophus meleagris, a filter-feeding scyphomedusa from the NE Gulf of Mexico. Estuar Coast Shelf Sci 32: 511-525

Lassuy DR (1989) Species profiles: life histories and environmental requirements of coastal fishes and invertebrates (Pacific Northwest) - Pacific herring. US Fish Wildl Serv Biol Rep 82(11.126):1-18

Last JM (1989) The food of herring, Clupea harengus, in the North Sea, 1983-1986. J Fish Biol 34:489-501

Macer CT (1966) Sand eels (Ammodytidae) in the south-western North Sea: their biology and fishery. Fish Invest Ser II Mar Fish GB, Minist Agric Fish Food Ser 2 24(6):1-55

Malej A (1982) Unusual occurrence of Pelagia noctiluca in the Adriatic. Acta Adriat 23:97-102

Mansueti R (1963) Symbiotic behaviour between small fishes and jellyfishes, with new data on that between the stromateid, Peprilus alepidotus, and the scyphomedusae, Chrysaora quinquecirrha. Copeia 1963:40-80

Manzer JI (1969) Stomach contents of juvenile Pacific salmon in Chatham sound and adjacent waters. J Fish Res Board Can 26:2219-2223

McGurk MD, Warburton HD (1992) Fisheries oceanography of the southeast Bering Sea: relationships of growth, dispersion and mortality of sand lance larvae to environmental conditions in the Port Moller Estuary. US Department of the Interior, Minerals Management Service, Anchorage (OCS Study MMS 92-0019)

McGurk MD, Warburton HD, Galbraith M, Kusser WC (1992) RNA-DNA ratio of herring and sand lance larvae from Port Moller, Alaska: comparison with prey concentration and temperature. Fish Oceanogr 1:193-207

Merati N, Brodeur R (1996) Feeding habits and daily ration of juvenile walleye pollock, Theragra chalcogramma, in the western Gulf of Alaska. NOAA Tech Rep NMFS 126:65-79

Meyer TL, Cooper RA, Langton RW (1979) Relative abundance, behavior, and food habits of the American sand lance, Ammodytes americanus, from the Gulf of Maine. Fish Bull 77:243-253

Mittelbach GG, Persson L (1998) The ontogeny of piscivory and its ecological consequences. Can J Fish Aquat Sci 55: $1454-1465$

Möller H (1980) Scyphomedusa as predators and food competitors of larval fish. Meeresforschung 28:90-100

Monteleone DM, Peterson WT (1986) Feeding ecology of American sand lance Ammodytes americanus larvae from Long Island Sound. Mar Ecol Prog Ser 30:133-143

Moulton LL (1997) Early marine residence, growth and feeding by juvenile salmon in northern Cook Inlet, Alaska. Alask Fish Res Bull 4:154-177
Munk P (1992) Foraging behaviour and prey size spectra of larval herring Clupea harengus. Mar Ecol Prog Ser 80: $149-158$

Nakatani T (1988) Studies on the early life history of walleye pollock Theragra chalcogramma in Funka Bay and vicinity, Hokkaido. Mem Fac Fish Hokkaido Univ 35:1-46

National Marine Fisheries Service (1999) Our living oceans. Report on the status of US living marine resources, 1999. NOAA Tech Memo NMFS. F/SPO-41:1-301

Orsi JA, Sturdevant MV, Murphy JM, Mortensen DG, Wing BL (2000) Seasonal habitat use and early marine ecology of juvenile Pacific salmon in southeastern Alaska. North Pac Anadromous Fish Comm Bull 2:(in press)

Pearre S Jr (1982) Estimating prey preference by predators: uses of various indices, and a proposal of another based on $\chi^{2}$. Can J Fish Aquat Sci 39:914-923

Perry RI, Hargreaves NB, Waddell BJ, Mackas DJ (1996) Spatial variations in feeding and condition of juvenile pink and chum salmon off Vancouver Island, British Columbia. Fish Oceanogr 5:73-88

Persson A, Hansson LA (1999) Diet shift in fish following competitive release. Can J Fish Aquat Sci 56:70-78

Purcell JE (1985) Predation on fish eggs and larvae by pelagic cnidarians and ctenophores. Bull Mar Sci 37:739-755

Purcell JE (1989) Predation by the hydromedusa Aequorea victoria on fish larvae and eggs at a herring spawning ground in British Columbia. Can J Fish Aquat Sci 46: $1415-1427$

Purcell JE (1992) Effects of predation by the scyphomedusan Chrysaora quinquecirrha on zooplankton populations in Chesapeake Bay. Mar Ecol Prog Ser 87:65-76

Purcell JE (1997) Pelagic cnidarians and ctenophores as predators: selective predation, feeding rates and effects on prey populations. Ann Inst Oceanogr 73:125-137

Purcell JE (1999) Jellyfish as competitors and predators of fishes. In: Duffy DC (ed) Exxon Valdez oil spill restoration project annual report (Restoration Project 98163S). University of Alaska, Anchorage, AK, p 383-432

Purcell JE, Arai MN (2001) Interactions of pelagic cnidarians and ctenophores with fish: a review. Hydrobiologia (in press)

Purcell JE, Grover JJ (1990) Predation and food limitation as causes of mortality in larval herring at a spawning ground in British Columbia. Mar Ecol Prog Ser 59:55-67

Purcell JE, Mills CE (1988) The correlation of nematocyst types to diets in pelagic Hydrozoa. In: Hessinger DA, Lenhoff HM (eds) The biology of nematocysts. Academic Press, San Diego, p 463-485

Purcell JE, Cresswell FP, Cargo DG, Kennedy VS (1991) Differential ingestion and digestion of bivalve larvae by the scyphozoan Chrysaora quinquecirrha and by the ctenophore Mnemiopsis leidyi. Biol Bull 180:103-111

Purcell JE, White JR, Roman MR (1994) Predation by gelatinous zooplankton and resource limitation as potential controls of Acartia tonsa copepod populations in Chesapeake Bay. Limnol Oceanogr 39:263-278

Purcell JE, Brown ED, Stokesbury KDE, Haldorson LJ, Shirley TC (2000) Aggregations of the jellyfish Aurelia labiata: abundance, distribution, association with age-0 walleye pollock, and behaviors promoting aggregation in Prince William Sound, Alaska, USA. Mar Ecol Prog Ser 195: 145-158

Robinson CJ, Pitcher TJ (1989) The influence of hunger and ration level on density, polarization and swimming speed of herring (Clupea harengus L). J Fish Biol 34:631-633

Rogers DE, Rabin DJ, Rogers BJ, Garrison KJ, Wangerin ME (1979) Seasonal composition and food web relationships 
of marine organisms in the nearshore zone of Kodiak Island - including ichthyoplankton, meroplankton (shellfish), zooplankton, and fish. University of Washington, Seattle (Fish Res Inst Annu Rep FRI-UW-7925)

Schmidt GM (1977) The exchange of water between Prince William Sound and the Gulf of Alaska. MS thesis, University of Alaska, Fairbanks

Schoener TW (1974) Resource partitioning in ecological communities. Science 185:27-39

Schweigert JF (1997) Role of Pacific herring in the British Columbia Marine ecosystem. Alask Sea Grant Rep Univ Alaska Fairbanks 97-01:655-681

Scott JS (1973) Food and inferred feeding behavior of northern sand lance (Ammodytes dubius). J Fish Res Board Can $30: 451-454$

Sekiguchi H (1977) Further observation on the feeding habits of planktivorous fish sand-eel in Ise Bay. Bull Jpn Soc Sci Fish 43:417-422

Sekiguchi H, Nagoshi M, Mori Y, Kato Y (1974) The feeding habits of larvae and juveniles of sand-eel, Ammodytes personatus (Girard), and anchovy, Engraulis japonica Houttuyn, in Ise Bay. Bull Fac Fish Mie Univ 1:34-41

Sherman K, Perkins HC (1971) Seasonal variation in the food of juvenile herring in coastal waters of Maine. Trans Am Fish Soc 1:121-124

Shiganova TA (1998) Invasion of the Black Sea by the ctenophore Mnemiopsis leidyi and recent changes in pelagic community structure. Fish Oceanogr 7:305-310

Simenstad CA, Salo EO (1982) Foraging success as a determinant of estuarine and nearshore carrying capacity of juvenile chum salmon (Oncorhynchus keta) in Hood Canal, Washington. Alask Sea Grant Rep Univ Alask Fairbanks 82-2:21-37

Simenstad CA, Miller BS, Nyblade CF, Thornburgh K, Bledsoe LJ (1979) Food web relationships of northern Puget Sound and the Strait of Juan de Fuca: a synthesis of available knowledge. NOAA Natl Mar Fish Serv Interag Energy/Environ Res Dev Prog Rep US Dep Comm EPA600/7-79-259:1-334

Sparks CE, Buecher E, Brierley AS, Axelsen BE, Boyer H, Gibbons MJ (2001) Observations on the distribution, and relative abundance of Chrysaora hysoscella (Linné, 1766) and Aequorea aequorea (Forskål, 1775) in the northern Benguela ecosystem. Hydrobiologia (in press)

Springer AM (1992) A review: walleye pollock in the North Pacific - how much difference do they really make? Fish Oceanogr 1:80-96

Springer AM, Speckman SG (1997) A forage fish is what? Summary of the symposium. In: Mecklenburg CW (ed) Forage fishes in marine ecosystems. University of Alaska, Fairbanks, p 773-805 (Alask Sea Grant Coll Prog Rep No. 97-01

Stokesbury KDE, Kirsch J, Brown ED, Thomas GL, Norcross BL (2000) Spatial distributions of Pacific herring (Clupea pallasi) and walleye pollock (Theragra chalcogramma) in Prince William Sound, Alaska. Fish Bull 98:400-409

Editorial responsibility: Kenneth Sherman (Contributing Editor), Narragansett, Rhode Island, USA
Sturdevant MV, Willette TM (1999) Diet composition, diet overlap and size of 14 species of forage fish collected monthly in Prince William Sound, Alaska, 1994-1996. Exxon Valdez oil spill restoration project final report (Restoration Project 97163C), Auke Bay Laboratory, National Marine Fisheries Service, Juneau

Sturdevant MV, Wertheimer AC, Lum JL (1996) Diets of juvenile pink and chum salmon in oiled and non-oiled nearshore habitats in Prince William Sound, 1989 and 1990. Am Fish Soc Symp 18:578-592

Sturdevant MV, Auburn ME, Hulbert LB, Brase ALJ (1997) Alaska predator ecosystem study: diet overlap, prey selection and potential food competition among forage fish species. In: Duffy DC (ed) Exxon Valdez oil spill restoration project annual report (Restoration Project 96163C). University of Alaska, Anchorage, AK, p 1-262

Sturdevant MV, Hulbert LB, Brase ALJ (1998) Alaska predator ecosystem study: diet overlap, prey selection, diel feeding periodicity and potential food competition among forage fish species. In: Duffy DC (ed) Exxon Valdez oil spill restoration project annual report (Restoration Project 97163C). University of Alaska, Anchorage, AK, p 1-72

Sullivan BK, Garcia JR, Klein-Macphee G (1994) Prey selection by the scyphomedusan predator Aurelia aurita. Mar Biol 121:335-341

Sutela T, Huusko A (2000) Varying resistance of zooplankton prey to digestion: implications for quantifying larval fish diets. Trans Am Fish Soc 129:545-551

Tsuda A, Saito H, Hirose T (1998) Effect of gut content on the vulnerability of copepods to visual predation. Limnol Oceanogr 43:1944-1947

van der Veer HW (1985) Impact of coelenterate predation on larval plaice Pleuronectes platessa and flounder Platichthys flesus stock in the Western Wadden Sea. Mar Ecol Prog Ser 25:229-238

Vinogradov ME, Shushkina EA, Bulgakova Yu V (1996) Consumption of zooplankton by the comb jelly Mnemiopsis leidyi and pelagic fishes in the Black Sea. Oceanology 35: 523-527

Wailes GH (1936) Food of Clupea pallasii in southern British Columbia waters. J Biol Board Can 1:477-486

Willette T, Sturdevant M, Jewett S (1997) Prey resource partitioning among several species of forage fishes in Prince William Sound, Alaska. In: Mecklenburg CW (ed) Forage fishes in marine ecosystems. University of Alaska, Fairbanks, p 11-29 (Alask Sea Grant Coll Prog Rep No. 97-01)

Willette TM, Cooney RT, Hyer K (1999) Predator foraging mode shifts affecting mortality of juvenile fishes during the subarctic spring bloom. Can J Fish Aquat Sci 56: 364-376

Zheng J (1977) Stock-recruitment relationships and recruitment patterns for forage fish stocks. In: Mecklenburg CW (ed) Forage fishes in marine ecosystems. University of Alaska, Fairbanks, p 655-681 (Alask Sea Grant Coll Prog Rep No. 97-01)

Submitted: May 25, 2000; Accepted: August 18, 2000

Proofs received from author(s): December 18, 2000 